\title{
ACCURACY OF MERGING POINT CLOUDS AT THE MAXIMUM RANGE OF A SCANNER WITH LIMITED POSSIBILITIES OF TARGET PLACEMENT
}

\author{
G. LENDA ${ }^{1}$, P. LEWIŃSKA ${ }^{2}$, J. SIWIEC ${ }^{3}$
}

\begin{abstract}
The research was aimed at analysing the factors that affect the accuracy of merging point clouds when scanning over longer distances. Research takes into account the limited possibilities of target placement occurring while scanning opposite benches of quarries or open-pit mines, embankments from opposite banks of rivers etc. In all these cases, there is an obstacle/void between the scanner and measured object that prevents the optimal location of targets and enlarging scanning distances. The accuracy factors for cloud merging are: the placement of targets relative to the scanner and measured object, the target type and instrument range. Tests demonstrated that for scanning of objects with lower accuracy requirements, over long distances, it is optimal to choose flat targets for registration. For objects with higher accuracy requirements, scanned from shorter distances, it is worth selecting spherical targets. Targets and scanned object should be on the same side of the void.
\end{abstract}

Keywords: laser scanning, long range, targets, registration accuracy, point cloud

\section{INTRODUCTION}

Measurements using laser scanning techniques are often carried out with unfavourable geometric placement of targets. This means that they cannot be freely distributed in the space between the instrument stations and the object that is being scanned. It is the case during the measuring of topographic objects and building structures, as exemplified by the scanning performed in quarries or

\footnotetext{
${ }^{1} \mathrm{PhD}$., associate professor, Eng., AGH University of Science and Technology, Faculty of Mining Surveying and Environmental Engineering, al. Mickiewicza 30, 30-059 Kraków, Poland, e-mail: grzenda@agh.edu.pl

${ }^{2} \mathrm{PhD}$., Eng., AGH University of Science and Technology, Faculty of Mining Surveying and Environmental Engineering, al. Mickiewicza 30, 30-059 Kraków, Poland, e-mail: lewinska.paulina@gmail.com

${ }^{3}$ M.Sc., Eng., AGH University of Science and Technology, Faculty of Mining Surveying and Environmental Engineering, al. Mickiewicza 30,30-059 Kraków, Poland, e-mail: jsiwiec@agh.edu.pl
} 
open-pit mines, when they are performed from the opposite benches of the excavation. Similarly, such situations may occur with the scanning of embankments, revetments or other elements of infrastructure from opposite banks of rivers or water reservoirs, as well as when measuring various elongated objects and structures located on the other side of communication routes. The problems may also arise with less typical applications, such as measuring the face of a glacier.

A common feature of such measurements is the occurrence of an elongated obstacle or a void between the object and the scanner. In some cases, it is possible to set the instrument on the same side of the obstacle as the object. However, for elongated objects, this significantly reduces the field of view of the scanner, forcing the stations to be placed closer to each other, which is time and data wiseunjustified. An elongated obstacle not only prevents a free placement of targets for merging point clouds from neighbouring stations, but it also makes it necessary to move the scanner away from the object by distances larger than required for the proper field of view of the scanner. This may cause problems with the instrument range and with the accuracy of determining the position of elements over long distances [7, 15, 18, 22].This may also limit the number and quality of data acquired in order to assess the technical condition of objects over an obstacle, such as bridges $[5,23]$ , making the technology unusable.

In the case of elongated obstacles, the targets can be placed either on the same side of the obstacle as the scanner, or on the opposite side, near the object. The scanning of these objects may, therefore, generate a problem emerging from the unfavourable geometry of the target distribution, associated with the lower accuracy of their determination if they are scanned over long distances. This problem has already been discussed in subject literature, as it regards both natural objects and large building structures $[3,4,11]$. As illustrated in Fig 1, two instances can be distinguished that affect the accuracy of merging point clouds.

In the first case, the targets will be located near the scanner stations and, at the same time, at a large distance from the object. Then, even small errors in targets identification may cause significant displacement of point clouds representing the object. In the second case, the targets will be located near the object, so this problem will not occur. However, the resolution and accuracy of long-range target scanning will be lower, having an adverse effect on the accuracy of merging point clouds. Moreover, in none of these cases the geometry of target placement will be optimal, i.e. it will be narrowed to the areas in front of or behind the obstacle $[3,16]$. 
The average width of potential obstacles may reach several dozen to several hundred meters, which means that the scanning will be performed over distances close to the actual maximum range of many popular instruments. This is yet another problem in such measurements [3].

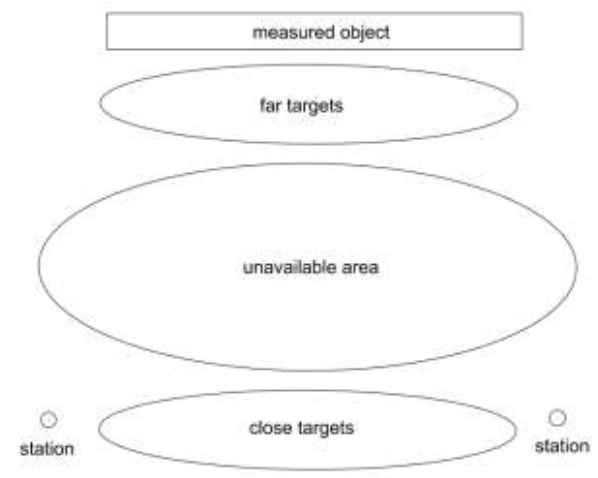

Fig. 1.Location of targets for inaccessible terrain between the instrument stations and the object

The accuracy of long-range scanning depends on the type of targets being used. The most popular ones include spherical targets, black and white checkerboard targets (b\&w) and HDS targets, produced by Leica. Not all of them may prove to be suitable for long-range measurements. But the distance may be affecting both the scanning accuracy and resolution $[2,6,10]$.

When measuring elongated objects, where long-range scanners are used, scanner stations are spaced at large distances. As a result, the measured objects and targets can be located at the ends of the scanning range [9]. The quality of a scan at the end of the range has a big influence on the recording accuracy, and hence on the final point cloud. The term "scan quality" is understood not only as the density of the point cloud but also as the reflection strength, beam divergence, reactions to various types of surfaces and colours $[9,11,19]$. The algorithm for recognising different types of targets, implemented in the internal software, is also important. All of these factors affect the way the target, i.e. the object with a defined shape and dimensions of the physical space, is mapped on the scan and where its centre is to be determined. Any changes in its appearance and shape on scans pose a significant problem during registration. Various authors have pointed out the lack of a standard in which the accuracy of a single scan is provided $[1,4]$. This accuracy is often related to the type of the measured object, where the colour, distance etc. are given, often without specifying the measurement conditions. Not all manufacturers provide information on standard measurement 
conditions (lighting, temperature, dustiness, humidity). Therefore, based on the specification only, it is difficult to determine the quality and usefulness of the results [7]. Scanner test procedures can be modelled on ISO standards similar for other surveying instruments [8].

Research studies that are currently being carried out aim at the optimal selection of target types [3, 9], their shape and colour [11, 19]. They include tests performed at various distances, in different lighting and at non-standard placement in relation to the scanner $[11,16]$. Studies on target types usually involve checking the effect of their colour on the behaviour of the laser beam $[6,11]$. The experiments are carried out on properly prepared colour charts. The results demonstrate that, depending on the type of the scanner, the smallest reflection intensity is produced by surfaces covered with black, dark red or navy blue colours. White and grey surfaces are characterised by high intensity. Some research has also been conducted regarding the materials which these targets are made of. Studies $[4,19]$ suggestthat plastics have exhibited the largest standard deviations that are increasing with the distance from the scanner. The use of plastics not covered by the material impermeable to the laser beam has also been excluded by the study [13]. Spherical targets are usually made of polystyrene, plastic or paint-coated plastic. Styrofoam spheres, the cheapest solution, are characterised by low unification of the shape. In addition, the laser beam penetrates into their centre, creating an ambiguous shape of the target. The spheres covered with matt paint are much better for testing purposes [12, 17, 21]. Other experiments related to the shape of targets have been carried out in $[6,9]$. The scans of good quality have been obtained for HDS targets and spheres, which have been clearly visible and their shapes have been evident. Due to the fact that HDS targets are better recognisable than black-and-white targets and that it is easier to determine their centre, they have obtained slightly better results.

The experiments are mostly carried out in laboratory conditions or at short distances. Field studies are also conducted for different distances $[3,9,10]$. As a result, it can be assessed, that over longer distances, the cloud can be rare and irregular, especially for dark-colored elements. The best results (the smallest standard deviations) are obtained at distances up to $100 \mathrm{~m}$ for HDS targets and for spheres at larger distances. B\&W targets results are much less reliable than those of HDS and spheres, they are also less visible on scans and have less clear edges. On distances above $200 \mathrm{~m}$ problems occur with automatic target recognition by software, mainly for smaller flat targets.

A comparison carried out by the manufacturer also provides interesting preliminary information about scanning measuring devices [24]. It demonstrates a higher accuracy of angle and length measurements for the Nova MS50 scanning station if compared to the ScanStation P20 scanner, but 
with higher measurement noise. The data is presented for a distance of 50 metres only, while these devices differ significantly in their measuring range.

In general, several factors affect the accuracy of merging point clouds when measuring objects over longer distances, with limited possibilities of target placement. These include: the placement of targets relative to each other, the scanner and the measured object, the type of targets, the type and range of instruments and the selected type of recording. Tests of the accuracy of merging point clouds, taking into account these factors, have been carried out.

\section{TEST PROCEDURE AND TEST RESULTS}

The conducted research has had several goals. The first one has been to determine whether there would be significant differences in the registering accuracy based on the close and distant targets from the perspective of the scanner (and, conversely, from the perspective of the object). The second objective has been to verify which of the targets (spherical, b\&w or HDS) have ensured the best accuracy of determining their centres in long-range measurements, comparable to the actual range of the tested scanners. The tests have been carried out for the distribution of the elements illustrated in Fig 2.

The measurements have been performed from two instrument stations: station 1 and station2. Sets of three targets and some tested objects have been scanned from each of them. The targets which have been used have included spherical targets for short-range scanning (cs1-cs3), and spherical (fs1fs3), b\&w (fb1-fb3) as well as HDS (fh1-fh3) targets for long distances. For shorter distances, the accuracy of each of these targets is good, so one type of the targets (spheres) has been selected. Certain doubts related to the accuracy of determining various targets usually arise for longer distances, which is why all types of sets have been tested in this case. The $b \& w$ targets have been flat checkerboards with the dimensions of $200 \times 200 \mathrm{~mm}$. Additional squares of reflective tape have been placed near their centres to increase the scanning range (Fig 3.a). The Leica HDS targets (Fig 3.b) have been 6" in size. The spherical targets have included Faro spheres with a diameter of $145 \mathrm{~mm}$ (Fig 3.c). The distant targets, located near the test object, have been arranged to simulate real conditions, when there is not enough space along the object for their surface distribution and therefore they assume a more elongated position, such as along flood embankments or excavation benches. The close targets, located on the same side of the obstacle as the scanner observation stations, have had a better mutual geometry, similar to an equilateral triangle. 

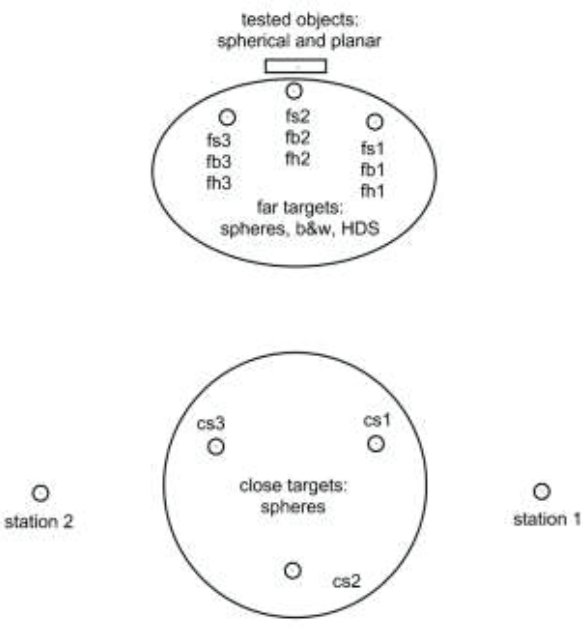

Fig. 2. Distribution of elements during tests
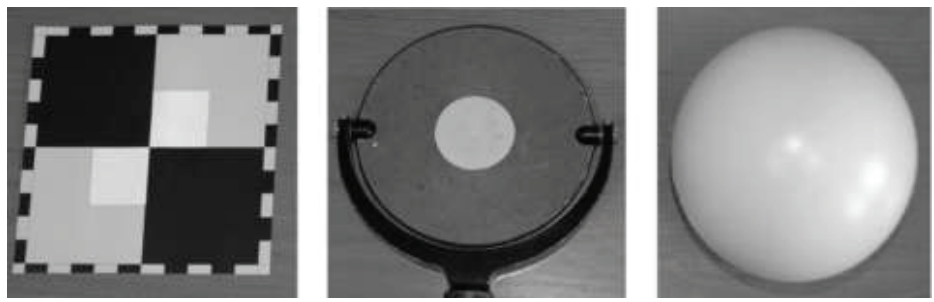

Fig. 3. Targets: (a) b\&w, (b) HDS, (c) Faro sphere

The test objects have included three types of the elements illustrated in Fig 4: planar targets (p1-p3) covered with reflective tape, Faro spherical targets (s1-s4) and HDS 6" flat targets. On these objects, the target accuracy of merging point clouds from two instrument stations has been tested.

The measurements have been performed using two instruments: the Leica ScanStation C-10 laser scanner and the Leica Nova MS-50 scanning total station. Such choice has been dictated by different types of potential measured objects: buildings and technical infrastructure as well as ground, rock, and similar objects. The first type of object requires a more detailed capture of their geometry and greater accuracy of measurement, while the second one needs a greater area and 
scanning distance. The ScanStation C-10 scanner has a range of up to $300 \mathrm{~m}$ and a precision of 2 $\mathrm{mm}$. The Nova MS-50 total station has four scanning modes differing in frequency $(1000,250,62$ and $1 \mathrm{~Hz})$, corresponding range $(300,400,500$ and $1000 \mathrm{~m})$ and precision $(6.0,3.0,2.0$, and 1.8 $\mathrm{mm}$ over a distance of $200 \mathrm{~m}$ ). The frequencies of $1 \mathrm{~Hz}$ and $62 \mathrm{~Hz}$ have been too low for testing, and the frequency of $1000 \mathrm{~Hz}$ has been associated with short range and low precision. Therefore, the mode $250 \mathrm{~Hz} / 400 \mathrm{~m} / 3.0 \mathrm{~mm}$ (frequency/range/precision) has been selected.

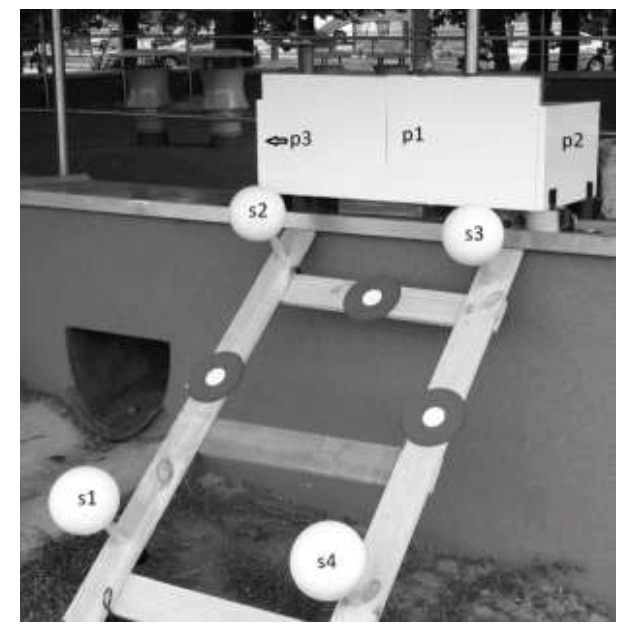

Fig. 4. Distribution of test objects

The distance at which the tests have been performed has been closely related to the maximum ranges of the instruments used, determined experimentally on the day of the measurements, so that all of the listed elements could be scanned. For the Nova MS-50 total station in the $250 \mathrm{~Hz}$ mode, the maximum test range has been about $300 \mathrm{~m}$, and for the ScanStation C-10 scanner it has been about $170 \mathrm{~m}$. The test objects from Fig 4 and distant target sets have been scanned at the maximum range. On the other hand, close targets have been set relative to the scanner at an average distance of about half of the maximum range.

Several types of analyses have been carried out to assess the accuracy of merging point clouds. The precision of fitting models into the clouds for individual types of test elements has been initially estimated. These elements have included planes and spheres. The average deviation of fitting into the cloud has been determined for both of them. Additionally the deviation of the model sphere diameter relative to the real one have been defined. The results for the ScanStation C-10 scanner are summarized in Table 1, and for the Nova MS-50 total station in Table 3. 
The basic analyses involved the determination of the accuracy of merging the point clouds using different configurations of the targets: close and distant: spheres, b\&w targets and HDS targets. The registration process has been carried out in the Leica Cyclone 9.0 program. The error values on the merging targets and on the four spheres (s1-s4) representing the test object have been determined. Afterwards, the differences in distances between the centres of the spheres s1-s4 from direct measurements and the spheres modelled from the merged point cloud were calculated. This way, the deformations of the spherical test object have been determined. Similar tests have been planned for the HDS targets illustrated on the test object as represented by Fig 4. However, due to their considerable horizontal and vertical inclination relative to the laser beam, these targets have been scanned with very low quality and could not form the basis for meaningful analyses. This applies to both tested instruments.

Another test object was also a rectangular box whose planes $\mathrm{p} 1$ and $\mathrm{p} 2$ have been measured from the first observation station, and $\mathrm{p} 1$ and $\mathrm{p} 3$ from the second station. This has allowed to determine the change in the length of the plane $\mathrm{p} 1$ relative to the direct measurement and the mutual transverse shift of this plane, resulting from the errors in the registering of the clouds from the two stations. The length of the $\mathrm{p} 1$ plane has been determined as follows: the $\mathrm{p} 1, \mathrm{p} 2$ and $\mathrm{p} 3$ planes have been fitted into the point cloud obtained as a result of the registration. Then, their intersections have been identified, whose distance has determined the searched length. This has allowed for an independent determination of the model length from the point cloud resolution on the $\mathrm{p} 1 \mathrm{plane}$. The change in the length of the p1 plane and its mutual shift resulting from the inaccuracy of merging the clouds from the two stations constitute two mutually orthogonal components of the deformation of the planar test object.Those changes has been taken into account in the further analyses.

The final accuracy of merging the clouds has therefore been specified for the test objects (spheres s1-s4 and planes p1-p3) by determining their deformations relative to the dimensions obtained from direct measurements. The results of the above analyses for the ScanStation C-10 scanner are summarized in Table 2, and for the Nova MS-50 scanning total station in Table 4. 
Table 1. Precision of model fitting into the cloud for test elements for ScanStation C-10 scanner

\begin{tabular}{|c|c|c|c|c|c|}
\hline \multirow{3}{*}{\multicolumn{2}{|c|}{$\begin{array}{l}\text { Leica } \\
\text { Scan Station C-10 }\end{array}$}} & \multicolumn{2}{|c|}{$\begin{array}{l}\text { average } \\
\text { fitting deviation }\end{array}$} & \multicolumn{2}{|c|}{$\begin{array}{l}\text { sphere diameter } \\
\text { deviation }\end{array}$} \\
\hline & & \multicolumn{4}{|c|}{$[\mathrm{mm}]$} \\
\hline & & \multicolumn{2}{|c|}{ station } & \multicolumn{2}{|c|}{ station } \\
\hline \multicolumn{2}{|c|}{ model } & st1 & st2 & st1 & st2 \\
\hline \multirow{4}{*}{$\begin{array}{c}\text { close } \\
\text { spherical } \\
\text { target }\end{array}$} & cs1 & 1.6 & 2.3 & 0.2 & 0.6 \\
\hline & $\operatorname{cs} 2$ & 1.9 & 2.1 & 0.5 & 0.7 \\
\hline & $\operatorname{cs} 3$ & 1.9 & 1.3 & 0.2 & 0.4 \\
\hline & mean & 1.8 & 1.9 & 0.3 & 0.6 \\
\hline \multirow{4}{*}{$\begin{array}{c}\text { far } \\
\text { spherical } \\
\text { target }\end{array}$} & fs1 & 2.1 & 3.1 & 1.3 & 2.2 \\
\hline & fs2 & 2.5 & 2.9 & 2.1 & 1.9 \\
\hline & fs 3 & 2.5 & 2.1 & 2.2 & 2.4 \\
\hline & mean & 2.4 & 2.7 & 1.9 & 2.2 \\
\hline \multirow{5}{*}{$\begin{array}{c}\text { test } \\
\text { sphere }\end{array}$} & s1 & 2.4 & 2.7 & 1.9 & 2.1 \\
\hline & s2 & 2.6 & 2.5 & 2.3 & 2.5 \\
\hline & s3 & 2.4 & 3.1 & 1.4 & 2.2 \\
\hline & s4 & 2.3 & 2.9 & 2.4 & 2.4 \\
\hline & mean & 2.4 & 2.8 & 2.0 & 2.3 \\
\hline \multirow{4}{*}{$\begin{array}{l}\mathrm{b} \& \mathrm{w} \\
\text { target }\end{array}$} & $\mathrm{fb} 1$ & 2.1 & 2.5 & - & - \\
\hline & $\mathrm{fb} 2$ & 2.8 & 2.7 & - & - \\
\hline & fb3 & 2.3 & 2.7 & - & - \\
\hline & mean & 2.4 & 2.6 & - & - \\
\hline \multirow{4}{*}{$\begin{array}{l}\text { HDS } \\
\text { target }\end{array}$} & fh1 & 2.4 & 2.2 & - & - \\
\hline & fh2 & 2.2 & 2.4 & - & - \\
\hline & fh3 & 2.3 & 2.2 & - & - \\
\hline & mean & 2.3 & 2.3 & - & - \\
\hline \multirow{4}{*}{$\begin{array}{l}\text { test } \\
\text { plane }\end{array}$} & $\mathrm{p} 1$ & 2.3 & 2.5 & - & - \\
\hline & p2 & 1.6 & - & - & - \\
\hline & p3 & - & 1.5 & - & - \\
\hline & mean & 2.0 & 2.0 & - & - \\
\hline
\end{tabular}

Table 2. Accuracy of merging point clouds using different target configurations for ScanStation C-10

\begin{tabular}{|c|c|c|c|c|c|}
\hline \multirow{2}{*}{ Leica Scan Station C-10 } & \multicolumn{4}{|c|}{ target type } \\
\cline { 3 - 6 } \multicolumn{2}{|c|}{ scanning distance: 170m } & $\begin{array}{c}\text { close } \\
\text { sphere } \\
\text { (cs) }\end{array}$ & $\begin{array}{c}\text { far } \\
\text { sphere } \\
\text { (fs) }\end{array}$ & $\begin{array}{c}\text { far } \\
\text { B\&W } \\
\text { (fb) }\end{array}$ & $\begin{array}{c}\text { far } \\
\text { HDS } \\
\text { (fh) }\end{array}$ \\
\cline { 3 - 6 } target registration error & 1 & 3.1 & 3.7 & 3.2 & 4.6 \\
& 2 & 2.1 & 3.1 & 3.7 & 5.3 \\
& 3 & 1.8 & 2.3 & 4.1 & 4.2 \\
\cline { 2 - 6 } & mean & $\mathbf{2 . 3}$ & $\mathbf{3 . 0}$ & 3.7 & $\mathbf{4 . 7}$ \\
\hline test sphere registration error & $\mathrm{s} 1$ & 6.2 & 2.4 & 3.8 & 5.5 \\
& $\mathrm{~s} 2$ & 4.2 & 2.1 & 3.3 & 4.2 \\
& $\mathrm{~s} 3$ & 6.7 & 3.1 & 4.3 & 3.1 \\
& $\mathrm{~s} 4$ & 6.7 & 4.5 & 3.9 & 4.5 \\
\cline { 2 - 6 } & mean & $\mathbf{6 . 0}$ & $\mathbf{3 . 0}$ & $\mathbf{3 . 8}$ & $\mathbf{4 . 3}$ \\
\hline test sphere distance deviation & $\mathrm{s} 1-\mathrm{s} 2$ & 11.2 & 5.1 & 7.4 & 5.7 \\
& $\mathrm{~s} 2-\mathrm{s} 3$ & 7.4 & 4.2 & 5.7 & 8.3 \\
& $\mathrm{~s} 3-\mathrm{s} 4$ & 12.6 & 7.5 & 6.1 & 5.4 \\
& $\mathrm{~s} 4-\mathrm{s} 1$ & 8.3 & 5.4 & 7.1 & 7.2 \\
\cline { 2 - 6 } & mean & $\mathbf{9 . 9}$ & $\mathbf{5 . 6}$ & $\mathbf{6 . 6}$ & $\mathbf{6 . 7}$ \\
\hline plane length deviation & $\mathrm{p} 1$ & 5.5 & 3.4 & 5.4 & 4.5 \\
\hline plane offset & $\mathrm{p} 1$ & 9.9 & 3.3 & 3.5 & 4.1 \\
\hline resultant plane deformation & $\mathrm{p} 1$ & $\mathbf{1 1 . 3}$ & $\mathbf{4 . 7}$ & $\mathbf{6 . 4}$ & $\mathbf{6 . 1}$ \\
\hline
\end{tabular}


Table 3. Precision of model fitting into the cloud for test elements for Nova MS-50 scanning total station

\begin{tabular}{|c|c|c|c|c|c|}
\hline \multirow{3}{*}{\multicolumn{2}{|c|}{$\begin{array}{l}\text { Leica } \\
\text { Nova MS-50 }\end{array}$}} & \multicolumn{2}{|c|}{$\begin{array}{l}\text { average } \\
\text { fitting deviation }\end{array}$} & \multicolumn{2}{|c|}{$\begin{array}{l}\text { sphere diameter } \\
\text { deviation }\end{array}$} \\
\hline & & \multicolumn{4}{|c|}{$[\mathrm{mm}]$} \\
\hline & & \multicolumn{2}{|c|}{ station } & \multicolumn{2}{|c|}{ station } \\
\hline \multicolumn{2}{|c|}{ model } & st1 & st2 & st1 & st2 \\
\hline \multirow{4}{*}{$\begin{array}{c}\text { close } \\
\text { spherical } \\
\text { target }\end{array}$} & $\operatorname{cs} 1$ & 3.7 & 5.1 & 1.2 & 3.1 \\
\hline & $\operatorname{cs} 2$ & 4.6 & 4.7 & 2.7 & 4.4 \\
\hline & $\operatorname{cs} 3$ & 4.7 & 3.6 & 2.4 & 2.6 \\
\hline & mean & 4.3 & 4.5 & 2.1 & 3.4 \\
\hline \multirow{4}{*}{$\begin{array}{c}\text { far } \\
\text { spherical } \\
\text { target }\end{array}$} & fs 1 & 6.1 & 7.3 & 7.2 & 5.5 \\
\hline & fs 2 & 6.3 & 6.8 & 5.4 & 6.2 \\
\hline & fs 3 & 7.7 & 6.1 & 4.3 & 7.1 \\
\hline & mean & 6.7 & 6.7 & 5.6 & 6.3 \\
\hline \multirow{5}{*}{$\begin{array}{c}\text { test } \\
\text { sphere }\end{array}$} & s1 & 8.6 & 8.8 & 8.2 & 6.5 \\
\hline & s2 & 7.6 & 7.2 & 5.8 & 5.1 \\
\hline & s3 & 6.7 & 8.5 & 7.7 & 7.2 \\
\hline & s4 & 6.5 & 9.1 & 7.1 & 8.8 \\
\hline & mean & 7.4 & 8.4 & 7.2 & 6.9 \\
\hline \multirow{4}{*}{$\begin{array}{l}\mathrm{b \& w} \\
\text { target }\end{array}$} & fb1 & 4.1 & 4.6 & - & - \\
\hline & $\mathrm{fb} 2$ & 5.1 & 5.6 & - & - \\
\hline & fb3 & 6.3 & 6.2 & - & - \\
\hline & mean & 5.2 & 5.5 & - & - \\
\hline \multirow{4}{*}{$\begin{array}{l}\text { HDS } \\
\text { target }\end{array}$} & fh1 & 6.6 & 7.3 & - & - \\
\hline & fh2 & 6.4 & 6.8 & - & - \\
\hline & fh3 & 5.6 & 7.1 & - & - \\
\hline & mean & 6.2 & 7.1 & - & - \\
\hline \multirow{4}{*}{$\begin{array}{l}\text { test } \\
\text { plane }\end{array}$} & $\mathrm{p} 1$ & 2.9 & 2.4 & - & - \\
\hline & p2 & 2.7 & - & - & - \\
\hline & p3 & - & 4.1 & - & - \\
\hline & mean & 2.8 & 3.3 & - & - \\
\hline
\end{tabular}

Table 4. Accuracy of merging point clouds using different target configurations for Nova MS-50 total station

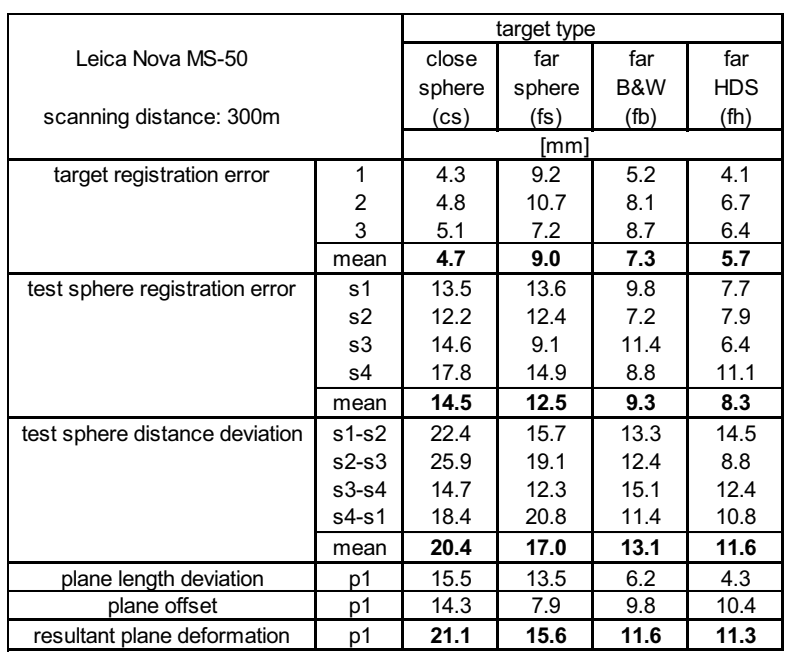




\section{ANALYSIS OF RESULTS}

\subsection{PRECision OF FITTING THE MODELS INTO THE POINT CLOUDS}

The precision of fitting the models into the point clouds representing the measured elements has been initially assessed (Tables 1 and 3). These elements have included the following targets: spherical and flat: b\&w and HDS, as well as the test objects: spherical and planar ones. The results captured with the $\mathrm{C}-10$ scanner have been characterised by much greater precision than with the MS-50 scanning station, and have been as follows: the mean deviation of fitting the model into a point cloud for the close elements (located relative to the scanner at the average distance of half the distance for the distant elements) has been less than $2 \mathrm{~mm}$. For the distant elements, despite their different types (spheres, b\&w and HDS targets), the mean deviations have had similar values of approximately $2.5 \mathrm{~mm}$. Higher differences in deviations have been observed for the p1-p3 test planes. The mean deviation of fitting the planes $\mathrm{p} 2$ and $\mathrm{p} 3$ has been about $1.5 \mathrm{~mm}$, and for the plane p1 it has been about $2.5 \mathrm{~mm}$ and it has been close to the deviations for the other distant elements onto which the beam has fallen orthogonally. During the experiment, the beam has fallen onto the planes $\mathrm{p} 2$ and $\mathrm{p} 3$ at a sharper angle than onto the plane p1. In general, the differences in the mean deviations for the close and distant targets have been insignificant and have reached an average of approximately $0.5 \mathrm{~mm}$. Greater discrepancies have been observed in the case of an additional parameter that could be determined for spherical elements, i.e. the difference between the diameter of the real and approximated sphere. For the close spheres, this average difference has been about $0.5 \mathrm{~mm}$, and for the distant spheres it has exceeded $2 \mathrm{~mm}$. The measurements performed at the first observation stand have had a slightly higher precision than at the second stand.

A significantly lower precision in fitting the models has been obtained for the elements scanned with the MS-50 total station. It has resulted from the scheme of the experiment: nearly twice as long scanning distance and the accompanying lower measurement precision in the selected scanning mode. For the close spherical elements, it has been about $4.5 \mathrm{~mm}$, and for the distant spheres it has been an average of just above $7 \mathrm{~mm}$. Distant planar elements (b\&w and HDS targets) have been fitted with an average deviation slightly below $6 \mathrm{~mm}$, while the test planes $\mathrm{p} 1-\mathrm{p} 3$ with the smallest deviation of all the elements, amounting to approximately $3 \mathrm{~mm}$. Therefore, for both instruments, the highest precision of fitting the models for the p1-p3 test planes has been noted, which must have resulted from covering their surfaces with a reflective foil. The average difference between the diameters of the real and the approximated spheres for the close spheres has been less than $3 \mathrm{~mm}$, 
and for the distant ones approximately $6.5 \mathrm{~mm}$. As it has been the case with the C-10 scanner, the observations made from the second station have been slightly more precise, with the measurements performed for both instruments in the afternoon hours. Therefore, a slight deterioration in precision may have resulted from a different insolation of the scanned elements compared to the first station, from which the measurements have been carried out earlier.

In general, the average precision of fitting the models for the C-10 scanner has been 2-3 times higher than for the MS-50 scanning station.

\subsection{ACCURACY OF MERGING POINT CLOUDS FOR SCANSTATION C-10 SCANNER}

The main tests concerned the determination of the accuracy of merging point clouds using different target configurations. Firstly, they have been discussed for the C-10 scanner (Table 2). The smallest errors in merging the targets have been obtained for the close spherical targets that have had the best precision of fitting the model. The average accuracy has been $2.3 \mathrm{~mm}$. The worse precision of fitting the models over greater distances has resulted in larger errors in merging the clouds. The mean error on the distant spherical targets has been $3.0 \mathrm{~mm}$, on the b\&w targets it has been $3.7 \mathrm{~mm}$, and on the HDS targets it has been the largest and has reached $4.7 \mathrm{~mm}$. It is worth paying attention to the look of point clouds for each type of targets (Fig 5). The cloud for the close sphere has by far the best consistency. For the distant sphere, it is noticeably worse, however, the registration errors are not significantly greater. To precisely identify the centre of the b\&w target, it was helpful to stick squares made of a reflective foil near its middle part. The HDS targets dedicated to the C-10 scanner have produced a relatively ambiguous picture of the central circle from a considerable distance, which has determined the lowest accuracy of merging the clouds with this type of a target. All targets measured with the C-10 scanner have been automatically recognised in the Cyclone program correctly and there has been no need to manually adjust the location of their centres.

After the registration, the errors have been read out on the test spheres s1-s4, which have not participated in the registration process. The largest mean error of $6 \mathrm{~mm}$ has been obtained for merging the point clouds using the spheres close to the scanner, which have also been the farthest from the test object. The smallest errors with an average value of $3.0 \mathrm{~mm}$ have occurred for the merging to the distant spherical targets, $3.8 \mathrm{~mm}$ for the merging to the b\&w targets and $4.3 \mathrm{~mm}$ to the HDS targets. 


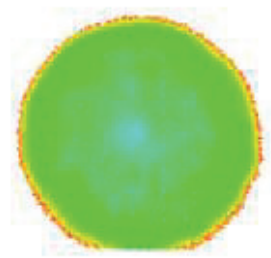

a)

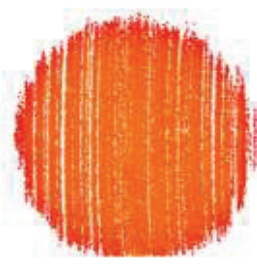

b)

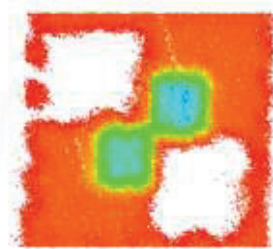

c)

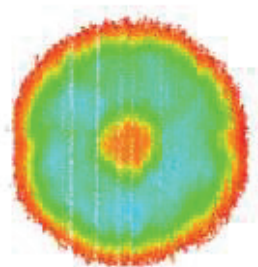

d)

Fig. 5. Point clouds measured with ScanStation C-10 scanner for each type of targets: close spheres (a), distant spheres (b), b\&w targets (c) and HDS targets (d). The figures illustrate the most representative of the three targets of each type

The differences between the centres of the test spheres s1-s4 from the direct measurements and the spheres modelled from the merged point cloud have also been determined, i.e. the deformations of the spherical test object. They have been similar for the different types of the distant targets and they have reached an average of about $6 \mathrm{~mm}$, and their smallest values have been obtained for the spherical targets. For the close targets, the average deformations have increased to about $10 \mathrm{~mm}$.

The last test has involved the determination of the difference in the length of the $\mathrm{p} 1$ plane relative to the direct measurement, and the mutual transverse shift of this plane derived from two clouds, measured from two stations. These changes correspond to the longitudinal and transverse components of the object deformation, resulting from the point clouds merging errors. Their resultant, which has been a deformation of the planar test object, has been assessed. This analysis has confirmed the previously observed accuracy relationships. The greatest error of approximately $11 \mathrm{~mm}$ has been obtained for the merging with close spherical targets. The smallest one, less than 5 $\mathrm{mm}$, has been obtained for the merging with distant spherical targets, and slightly larger, over 6 $\mathrm{mm}$, for the flat targets.

\subsection{ACCURACY OF MERGING POINT CLOUDS FOR NOVA MS-50 TOTAL STATION}

The results obtained for the Nova MS-50 scanning station (Table 4) had a noticeably worse precision and accuracy, which can be initially assessed by comparing the point cloud views captured with this instrument (Fig 6), with similar views for the ScanStation C-10 scanner (Fig 5).

The smallest errors in merging targets have been obtained for close spherical targets and they have reached an average of $4.7 \mathrm{~mm}$. The mean error for the distant spherical targets has been $9.0 \mathrm{~mm}$, for the b\&w targets it has been $7.3 \mathrm{~mm}$, and for the HDS targets it has been $5.7 \mathrm{~mm}$. The centres of the 
spherical targets have been determined automatically, based on LSM spheres being fitted (with outliers elimination) into the point clouds. However, none of the centres of the flat targets has been recognised correctly automatically, and it has been therefore necessary to determine them manually. In this case, the determination of the centre of the b\&w targets (Fig. 6.c) has been encumbered with a greater uncertainty than the HDS targets (Fig 6.d). The merging of the distant spherical targets has turned out to be the least accurate, which has resulted from the automatic fitting of the spheres with a $7 \mathrm{~mm}$ precision, with a $6 \mathrm{~mm}$ deviation of the diameter of the model sphere from the real one. Manual recognition of the centre of the sphere for such a highly scattered cloud (Fig 6.b) has yielded worse results than the automatic one, and it has not been used.

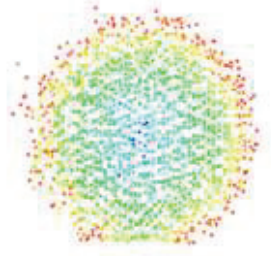

a)

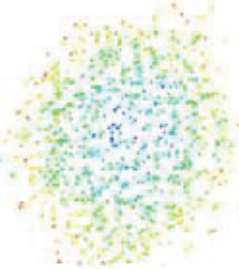

b)

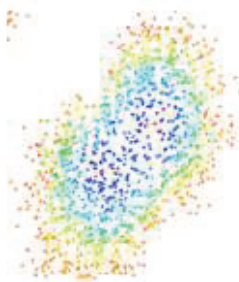

c)

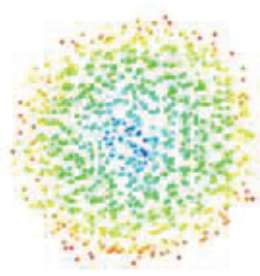

d)

Fig. 6. Point clouds recorded with Nova MS-50 scanning total station for each type of targets: close spheres (a), distant spheres (b), b\&w targets (c) and HDS targets (d). The figures illustrate the most representative of the three targets of each type

The errors on the test spheres s1-s4, which have not participated in the registration process, have been the largest for the merging of the clouds using the close spherical targets and have reached nearly $15 \mathrm{~mm}$. The smallest errors with the values of 9 and $8 \mathrm{~mm}$ have been obtained for the merging with the distant $b \& w$ and HDS targets. The errors of about $13 \mathrm{~mm}$ have been obtained for the merging with distant spherical targets.

Then, the deformations of the spherical test object have been defined. For this purpose, the differences between the centres of the test spheres s1-s4 from the direct measurements and the spheres modelled from the merged point clouds have been identified. Their smallest mean values, of about $12 \mathrm{~mm}$, have been obtained for merging the clouds using the HDS targets, and about $13 \mathrm{~mm}$ for the b\&w targets. Larger mean differences, of about $17 \mathrm{~mm}$, have occurred while merging with the distant spherical targets, and the largest ones, of about $20 \mathrm{~mm}$, while merging with the close targets. 
The deformations of the planar test object have been similar, defined as the resultants of the changes determined based on the test planes (changes in the lengths of the planes and their shifts). The largest deformation of approximately $21 \mathrm{~mm}$ has been observed for the merging with the close spherical targets, the smallest one (of about 11-12 $\mathrm{mm}$ ) for both flat targets, and for the distant spherical targets it has slightly exceeded $15 \mathrm{~mm}$.

\subsection{COMPARISON OF REGISTRATION ERRORS FOR BOTH INSTRUMENTS}

A general comparison of the results for both instruments has brought the following observations. The smallest errors in fitting the targets have been obtained for the close spherical targets. However, since they have been located far away from the test objects, the largest deformations have occurred on these objects, resulting from the registration errors. They have reached the average value of the shift vector slightly above $10 \mathrm{~mm}$ for the C-10 scanner and slightly above $20 \mathrm{~mm}$ for the MS-50 scanning total station. The targets placed at a greater distance from the scanner have had worse precision of fitting the model, but because they have been closer to the test objects, they have allowed for the reduction of the mutual cloud shift. For the ScanStation C-10 scanner and the distant flat b\&w and HDS targets, the average deformations of the test objects have slightly exceeded $6 \mathrm{~mm}$. For the distant spherical targets, the deformations have turned out to be the smallest and have reached approximately $5 \mathrm{~mm}$. In the case of the Nova MS-50 total station and the distant targets, the situation has been the opposite. The smallest average deformations of the test objects have occurred for the merging of the clouds using the HDS targets and they have reached approximately $11 \mathrm{~mm}$,slightly larger deformations (of about $12 \mathrm{~mm}$ ) have occurred for the merging of the b\&w targets. The largest, of approximately $16 \mathrm{~mm}$, have occurred for the merging of the clouds using distant spherical targets. The results obtained for the spherical targets, which have been worse than for the flat targets, have resulted from the low precision of the MS-50 scanning total station. For the flat targets (b\&w and HDS targets), it has been possible to determine their centres manually quite correctly, because this process has been carried out in a plane. For the spherical targets, the manual spatial determination of their centres has not been satisfactory, and therefore they have been determined automatically (LSM with outliers elimination) which, with low scanning precision, has failed to achieve better results.

The average deformations of the test objects for the C-10 scanner were within 5-10 mm depending on the targets, and for the MS-50 scanning total station they were about twice as large, within the range of about 11-20 $\mathrm{mm}$. 


\section{SUMMARY}

The performed research has been aimed at analysing the factors affecting the accuracy of merging point clouds when measuring objects over longer distances, with limited possibilities of target placement. The considered situation has involved the occurrence of an obstacle/void between the scanner and the measured object, which has made optimal placement of the targets impossible. The factors taken into account during the tests have included: the placement of targets relative to each other, relative to the scanner and to the measured object, the type of targets and the range of instruments.

The performed research studies have demonstrated that if it is not possible to place the targets freely between the instrument station and the object, it is optimal to place them behind an obstacle on the side of the object. They will be merged with a smaller precision of determining the centres of the targets, resulting from scanning at large distance. However, the higher precision of scanning the targets placed in front of the obstacle, on the side of the scanner stand, has not allowed to obtain better accuracy of merging the clouds. When selecting the optimal type of targets, these accuracies have been about twice better for distant targets (located on the side of the object) than for the close ones (located on the scanner side).

The targets subjected to long-range scanning tests have included both spherical and flat targets (b\&w and HDS targets). Their optimal selection has turned out to be dependent on the precision of long-range scanning of these elements (close to the actual range of the instruments). For the C-10 scanner, this precision has been relatively high and it has been possible to automatically identify the correct centres for all types of targets. The best accuracy of merging the point clouds has been obtained for the spherical targets and it has been about 25\% higher than for the flat targets (b\&w and HDS ones), for which the accuracy has been comparable. A different accuracy characteristic has been obtained for low precision measurements using the MS-50 total station. In this case, correct automatic recognition of flat targets has proved to be impossible. The centres of the spherical targets have been automatically determined. The most accurate determination of the centres has been performed for the HDS targets, allowing for a few percent higher accuracy of merging the clouds than for the b\&w targets, and for over $40 \%$ higher accuracy compared to the automatically determined spherical targets.

All in all, it can be stated that it is preferable to select flat targets for the scanning with lower accuracy requirements (e.g. of natural forms), performed over long distances and with low precision 
(Nova MS-50 scanning total station). For objects with higher accuracy requirements (e.g. technical infrastructure), scanned from shorter distances but with better precision (ScanStation C-10 scanner), it is worth selecting spherical targets. In any case, the targets should be placed on that side of the obstacle/void on which the object being measured is located.

\section{ACKnOwledgement: The article was prepared under the research subvention of AGH University of Science and Technology No. 16.16.150.545 in 2019.}

\section{REFERENCES}

1. Balzani M, Pellegrinelli A, Perfetti N, Uccelli F (2001) A Terrestrial 3D Laser Scanner: Accuracy Tests. Proceedings of the 18th International CIPA Symposium. pp 445-453

2. Boehler W, Bordas Vincent M, MarbsA (2003) Investigating laser scanner accuracy, originally presented at the XIXthCipa Symposium at Antalya. Turkey. 30 SEP - 4 OCT 2003 UPDATED for web presentation October 2003

3. Burcin BG, Jazizadeh F, Kavulya G, Calis G (2011) Assessment of target types and layouts in 3D laser scanning for registration accuracy. Automation in Construction. 20: 649-658. https://doi.org/10.1016/j.autcon.2010.12.008

4. Cheok SG, Stone WC (2007) Performance evaluation facility for LADARs. Proceedings of SPIE — Laser Radar Technology and Applications IX, vol. 5412, 2007, pp 54-65

5. Chróścielewski J, Miśkiewicz M, Pyrzowski Ł, Sobczyk B. (2018) Damage Analysis of Tensioning Cable Anchorage Zone of a Bridge Superstructure, Using CDP Abaqus Material Model. Archives of Civil Engineering, 63(3), 3-18, DOI: https://doi.org/10.1515/ace-2017-0025

6. Csanyi N, TothChT (2007). Improvement of Lidar Data Accuracy Using Lidar-Specific Ground Targets. Photogrammetric Engineering \& Remote Sensing. https://doi.org/10.14358/PERS.73.4.385

7. Cuartero A, Armesto J, Rodriguez GR, Pedro A (2010) Error Analysis of Terrestrial Laser Scanning Data by Means of Spherical Statistics and 3D Graphs. Sensors. https://doi.org/10.3390/s101110128

8. Gottwald R. (2008) Field Procedures for Testing Terrestrial Laser Scanners (TLS) A Contribution to a Future ISO Standard. Integrating Generations FIG Working Week 2008 Stockholm. Sweden 14-19 June 2008

9. Hiremagalur J, Yen K, Lasky T, Ravani B (2009) Testing and Performance Evaluation of Fixed Terrestrial 3D Laser Scanning Systems for Highway Applications. Transportation Research Board 88th Annual Meeting, 2009

10. Kersten T, Mechelke K, Lindstaed M, Sternberg H (2009) Methods for Geometric Accuracy Investigations of Terrestrial Laser Scanning Systems. PhotogrammetrieFernerkundungGeoinformation 4:301-316. https://doi.org/10.1127/1432-8364/2009/0023

11. Kersten T, Sternberg H, Mechelke K (2005) Investigations into the accuracy behaviour of the terrestrial laser scanning system Mensi GS100. Optical 3-D Measurement Techniques VII. 1: pp 122-131. 
12. Lenda G, Marmol U, Buczek M (2018) The effect of partial transparency of spherical targets on TLS point clouds registration accuracy. KSCE Journal of Civil Engineering. 22:2538-2548 https://doi.org/10.1007/s12205-017-1907-9

13. Lenda G, Marmol U, Mirek G (2015) Accuracy of laser scanners for measuring surfaces made of synthetic materials. PhotogrammetrieFernerkundungGeoinformation, H. 5:357-372 DOI: 10.1127/pfg/2015/0273

14. Lewińska P, Kamiński P, Proficz P, Kubiak S (2016) Inwentaryzacja stanu prac remontowych komory „Gaisruck" w Kopalni Soli „Wieliczka" (Inventory measurement of „Gaisruck” chamber at „Wieliczka" Salt Mine). WiadomościGórnicze ; ISSN 0043-5120.

15. Lewińska P, Matuła R, Dyczko A (2017) Integration of thermal digital 3D model and a MASW (Multichannel Analysis of Surface Wave) as a means of improving monitoring of spoil tip stability, BGC Geomatics 2017 Baltic Geodetic Congress (Geomatics) : 22-25 June 2017, Gdansk, Poland, e-ISBN: 978-1-5090-6040-5, https://goo.gl/djwL7C

16. Lichti DD, Stewart MP, Tsakiri M, Snow AJ (2000) Calibration and testing of a terrestrial laser scanner. International Archives of Photogrammetry and Remote Sensing. Vol. XXXIII, Part B5, Amsterdam, http://www.isprs.org/proceedings/XXXIII/congress/part5/485_XXXIII-part5.pdf

17. Muralikrishnan B, Rachakonda P, Lee V, Shilling M, Sawyer D, Cheok G, Cournoyer L (2017) Relative range error evaluation of terrestrial laser scanners using a plate, a sphere, and a novel dual-sphere-plate target. Measurement. https://doi.org/10.1016/j.measurement.2017.07.027

18. Pętlicki M, KinnardCh (2016) Calving of FuerzaAérea Glacier (Greenwich Island, Antarctica) observed with terrestrial laser scanning and continuous video monitoring, Journal of Glaciology, 62(235):835-846 https://doi.org/10.1017/jog.2016.72

19. Pfeifer N, Dorninger P, Haring A, Fan H (2007) Investigating terrestrial laser scanning intensity data: quality and functional relations. 8th Conference on Optical 3-D Measurement Techniques.

20. Podgórski J, Pętlicki M, KinnardCh (2018) Revealing recent calving activity of a tidewater glacier with terrestrial LiDAR reflection intensity. Cold Regions Science and Technology. 151:288-301. https://doi.org/10.1016/j.coldregions.2018.03.003

21. Rachakonda P, Muralikrishnan B, Cournoyer L, Cheok G, Lee V, Shilling M, Sawyer D (2017) Methods and considerations to determine sphere center from terrestrial laser scanner point cloud data. Measurement Science and Technology https://doi.org/10.1088/1361-6501/aa8011

22. Zaczek-Peplinska J, Kowalska M (2017) Terrestrial laser scanning in monitoring of anthropogenic objects. Geodesy and Cartography. 66:347-364. https://doi.org/10.1515/geocart-2017-0011

23. Zobel H, Karwowski W, Wróbel M, Mossakowski P (2017) Łazienkowski Bridge Fire in Warsaw - Structural Damage and Restoration Method. Archives of Civil Engineering, 62(4), 171-186, DOI: https://doi.org/10.1515/ace-2015-0104

24. Leica geosystems tutorial; Leica MS50 Comparison to HDS, https://cdn.ymaws.com/www.njspls.org/resource/resmgr/Docs/LASERSCANNING.pdf 


\section{LIST OF FIGURES AND TABLES:}

Fig. 1.Location of targets for inaccessible terrain between the instrument stations and the object

Rys. 1. Położenie targetów w przypadku niedostępnego terenu pomiędzy stanowiskami instrumentu a skanowanym obiektem

Fig. 2. Distribution of elements during

Rys. 2. Rozmieszczenie elementów podczas badań testowych

Fig. 3. Targets: (a) b\&w, (b) HDS, (c) Faro sphere

Rys. 3. Cele: (a) czarno-biale, (b) HDS, (c) kole Faro

Fig. 4. Distribution of test objects

Rys. 4. Rozmieszczenieobiektówtestowych

Fig. 5. Point clouds measured with ScanStation C-10 scanner for each type of targets: close spheres (a), distant spheres (b), b\&w targets (c) and HDS targets (d). The figures illustrate the most representative of the three targets of each type

Rys. 5. Chmury punktów zarejestrowane skanerem Scanstation C-10 dla każdego rodzaju targetów: sfer bliskich (a), sfer dalekich (b), tarcz b\&amp;w (c) i tarcz HDS (d). Rysunki przedstawiają widok najbardziej reprezentatywnego $\mathrm{z}$ trzech targetów każdego rodzaju.

Fig. 6. Point clouds recorded with Nova MS-50 scanning total station for each type of targets: close spheres (a), distant spheres (b), b\&w targets (c) and HDS targets (d). The figures illustrate the most representative of the three targets of each type

Rys. 6. Chmury punktów zarejestrowane tachimetrem Nova MS-50 dla każdego rodzaju targetów: sfer bliskich (a), sfer dalekich (b), tarcz b\&amp;w (c) i tarcz HDS (d). Rysunki przedstawiają widok najbardziej reprezentatywnego z trzech targetów każdego rodzaju.

Table 1. Precision of model fitting into the cloud for test elements for ScanStation C-10 scanner

Tab. 1. Precyzja wpasowania modelu w chmurę elementów testowych dla skanera Scanstation C-10

Table 2. Accuracy of merging point clouds using different target configurations for ScanStation C-10

Tab. 2. Dokładność łączenia chmur punktów przy użyciu różnych konfiguracji targetów dla skanera Scanstation C-10

Table 3. Precision of model fitting into the cloud for test elements for Nova MS-50 scanning total station

Tab. 3. Precyzja wpasowania modelu w chmurę dla elementów

testowych dla tachimetru skanującego Nova MS-50

Table 4. Accuracy of merging point clouds using different target configurations for Nova MS-50 total station Tab. 4. Dokładność łączenia chmur punktów przy użyciu różnych konfiguracji targetów dla tachimetru skanującego Nova MS-50 


\section{DOKŁADNOŚĆ ŁĄCZENIA CHMUR PUNKTÓW DLA POMIARU NA ODLEGLOŚCIACH ZBLIŻONYCH DO RZECZYWISTEGO ZASIĘGU SKANERA PRZY OGRANICZONEJ MOŻLIWOŚCI USYTUOWANIA TARGETÓW}

Keywords: skanowanie laserowe, skanowanie dlaekiego zasiegu, cele, dokladnosc rejestracji

STRESZCZENIE: Badania miały na celu przeanalizowanie czynników wpływających na dokładność łączenia chmur punktów przy pomiarze obiektów na większych odległościach, przy ograniczonej możliwości rozmieszczenia targetów. Sytuacje takie mogą występować np. podczas skaningu w kamieniołomach lub kopalniach odkrywkowych, kiedy pomiar odbywa się z przeciwległych teras wyrobiska. Mogą pojawić się również podczas skanowania obwałowań, umocnień brzegów czy innych elementów infrastruktury z przeciwległego brzegu rzek czy zbiorników wodnych. Podobna sytuacja może wystąpić podczas pomiarów rozmaitych wydłużonych obiektów i budowli położonych po drugiej stronie tras komunikacyjnych. We wszystkich tych przypadkach pomiędzy stanowiskami skanera a mierzonym obiektem pojawia się przeszkoda/pustka, uniemożliwiająca optymalne usytuowane targetów łączących chmury punktów i zwiększająca odległości, na których wykonywany jest skaning. Czynnikami wpływającymi na dokładność łączenia chmur są w takich przypadkach: rozmieszczenie targetów względem siebie, skanera i mierzonego obiektu, rodzaj targetów oraz zasięg instrumentów. Zostały one uwzględnione w przeprowadzonych badaniach, mających wyłonić optymalną konfigurację pomiarową.

Zaplanowano eksperyment,w którym obiekty testowe o ściśle określonej geometrii mierzono z dwóch stanowisk skanera, na odległościach bliskich rzeczywistemu, maksymalnemu zasięgowi instrumentów. Chmury punktów reprezentujące te obiekty, składano następnie w całość przy wykorzystaniu popularnych rodzajów targetów o różnym wzajemnym usytuowaniu. Wstępnie sprawdzano precyzję wpasowania modeli w chmurę dla poszczególnych rodzajów elementów testowych (kul i płaszczyzn), dla pomiarów wykonanych z pojedynczego stanowiska. Następnie określonodokładność łączenia chmur punktów z obydwu stanowisk przy użyciu różnych konfiguracji targetów. Wyznaczony został błąd rejestracji na poszczególnych targetach, a następnie jego wpływ na dokładność odwzorowania elementów testowych, umieszczonych w małej lub dużej odległości od targetów. Do pomiarów wykorzystano instrumenty o różnym zasięgu, szybkości i precyzji skanowania: skaner laserowy Leica ScanStation C10 i tachimetr skanujący Leica Nova MS-50. Łączenie chmur punktów przeprowadzono w oprogramowaniu Leica Cyclone 9.0.

Badania pozwoliły zweryfikować czy występują istotne różnice w dokładności rejestracji w oparciu o targety bliskie i dalekie z perspektywy skanera (i równocześnie odwrotnie z perspektywy obiektu). Określono również, które spośród celów: sferyczne, b\&w i HDS zapewniają najlepszą dokładność rejestracji na dużych odległościach, porównywalnych z rzeczywistym zasięgiem skanera.

W wyniku testów ustalono, że dla skanowania obiektów o niższych wymaganiach dokładnościowych (np. formy naturalne), prowadzonego na dużych odległościach i przy niskiej precyzji (testowany tachimetr MS-50), do łączenia chmur punktów korzystnie jest wybranie targetów płaskich. Dla obiektów o wyższych wymaganiach dokładnościowych (np. infrastruktura techniczna), skanowanych na mniejszych odległościach, ale z większą precyzją (testowany skaner C10), warto wybrać targety sferyczne. W każdym przypadku targety powinny być umiejscowione po tej stronie przeszkody/pustki, po której znajduje się mierzony obiekt. 